\section{Effects of Postharvest Curing, Ozone, Sulfur Dioxide, or Low Oxygen/High Carbon Dioxide Storage Atmospheres on Quality of Short-day Onions}

\author{
Manish K. Bansal ${ }^{1,3}$, George E. Boyhan ${ }^{1,4,6}$, \\ and Daniel D. MacLean ${ }^{2,5}$
}

ADDITIONAL INDEX WORDS. spring onions, nonstorage onions, controlledatmosphere storage, botrytis neck rot, Botrytis alli, Allium cepa

Summary. Vidalia onions (Allium cepa) are a branded product of southeastern Georgia marketed under a federal marketing order. They are short-day, yellow onions with a Granex shape that are susceptible to a number of diseases postharvest, limiting the amount of time they can be marketed. Postharvest treatments and storage methods can help extend their marketability. Thus, the objective of this study was to evaluate these postharvest treatments and storage conditions on quality of three Vidalia onion varieties: 'WI-129', 'Sapelo Sweet', and 'Caramelo'. All varieties were undercut, then either harvested immediately (zero cure), field cured ( 2 days), or forced-air heat cured ( 3 days at $\left.\approx 37^{\circ} \mathrm{C}\right)$ when judged mature. 'WI-129', 'Sapelo Sweet', and 'Caramelo' represent early, midseason, and late varieties, respectively. Bulbs were then sorted and stored in refrigerated storage $\left[0-1{ }^{\circ} \mathrm{C}, 70 \%\right.$ relative humidity $(\mathrm{RH})]$, sulfur dioxide $\left(\mathrm{SO}_{2}\right)\left(1000 \mathrm{mg} \cdot \mathrm{L}^{-1}\right.$ in 2010 and 5000 $\mathrm{mg} \cdot \mathrm{L}^{-1}$ in 2011 , one time fumigation) followed by refrigeration, ozone $\left(\mathrm{O}_{3}(0.1-\right.$ $10 \mathrm{mg} \cdot \mathrm{L}^{-1}$; continuous exposure, $\left.0-1{ }^{\circ} \mathrm{C}, 70 \% \mathrm{RH}\right)$, or controlled-atmosphere storage [ $3 \%$ oxygen $\left(\mathrm{O}_{2}\right), 5 \%$ carbon dioxide $\left(\mathrm{CO}_{2}\right), 0-1{ }^{\circ} \mathrm{C}, 70 \% \mathrm{RH}$ ]. After 2 and 4 months, bulbs were removed from storage, and evaluated after 1 and 14 days for quality and incidence of disorders. 'Caramelo' had the lowest percent marketable onions after curing in 2010, while 'WI-128' had the lowest percent marketable onions in 2011. There was a rain event immediately before harvesting 'Caramelo' that may have contributed to low marketability in 2010. Heat curing improved marketability for 'Sapelo Sweet' and 'WI-129' in 2010 compared with no curing. In 2011 , heat curing resulted in more marketable onions for 'Sapelo Sweet' compared with no curing. Curing had no effect on 'Caramelo' in 2011 and field curing had the greatest percent marketable onions for 'WI-129' in 2011. In 2010, controlledatmosphere storage had more marketable onions compared with $\mathrm{SO}_{2}$ for ' $\mathrm{Car}$ amelo' and was better than simple refrigeration or $\mathrm{O}_{3}$ with 'WI-129'. In 2011 refrigeration, controlled-atmosphere storage, and $\mathrm{O}_{3}$ were all better than $\mathrm{SO}_{2}$ with 'Caramelo'. 'Sapelo Sweet' and 'WI-129', on the other hand in 2011, had better storage with $\mathrm{SO}_{2}$ compared with other storage methods. Onions stored for 2 months had $32 \%$ and $17 \%$ more marketable onions after removal compared with 4 months of storage regardless of storage conditions for 2010 and 2011 , respectively. Poststorage shelf life was reduced by about one-third, 14 days after removal from storage regardless of the storage conditions.

$\mathrm{W}$ orldwide, the United States ranks third in the production of dry bulb onions after China and India (Food and Agriculture Organization of the United Nations, 2014). The Vidalia onion industry is an important component of Georgia's

${ }^{1}$ Department of Horticulture, University of Georgia, 1111 Miller Plant Science Building, Athens, GA 30602

${ }^{2}$ Department of Horticulture, University of Georgia, 4604 Research Way, Tifton, GA 31794

${ }^{3}$ Former graduate student

${ }^{4}$ Professor and Extension Vegetable Specialist

${ }^{5}$ Former Assistant Professor and currently New Business Development Research Manager, AgroFresh

${ }^{6}$ Corresponding author. E-mail: gboyhan@uga.edu. agricultural economy, and is a significant portion of the U.S. onion market. Vidalia onions are a branded product protected by both state recognition and a federal marketing order. They are a short-day, yellow, high water content onion with a Granex shape. In 2010, almost 13,000 acres were harvested in Georgia with an estimated farm gate value of \$139 million (Wolfe and Morgan, 2011). Onions ranked first among vegetables comprising $\approx 18.5 \%$ of total vegetable farm gate value in Georgia (Wolfe and Morgan, 2011), which makes onions the state's most important vegetable crop.

Onions are divided into three categories based on the photoperiod length plants need to initiate bulb production, 1 ) short-day varieties that require $11-12 \mathrm{~h}$ of daylight, 2) intermediate-day varieties that will bulb when exposed to $13 \mathrm{~h}$ of daylight, and 3) long-day varieties that will bulb when exposed to photoperiods for 14-16 h (Brewster, 1990). Onions from different daylength classifications also have other significant differences, notably the degree of pungency and storability with short-day onions generally having the lowest pungency and the poorest storability. Due to the mild winter and early spring season in Georgia, short-day varieties are well suited for overwintering production in the state (Boyhan and Torrance, 2002).

Vidalia onions are relatively low in sulfur compounds, which makes them mild flavored (Boyhan and Torrance, 2002). However, having the characteristic of low sulfur content makes Vidalia onions more susceptible to infection from pathogens and diseases than high sulfur-containing onions (Maw et al., 1997b). Several fungal pathogens can attack sweet onions in Georgia. Botrytis neck rot (Botrytis alli) is one of the most common and damaging storage pathogens of short-day onions. In bad years, $70 \%$ of the total crop can be infected with botrytis neck rot rendering them unmarketable (Sanders et al., 2008). Under natural conditions, this pathogen infects the dead or dying tissue of the onion bulb, and then grows downward through the neck into the bulb proper (Pappelis et al., 1974).

The postharvest treatment required for long-term storage of onions is curing (Maw et al., 1997a). Curing

\begin{tabular}{llll}
\hline $\begin{array}{l}\text { Units } \\
\begin{array}{l}\text { To convert U.S. to SI, } \\
\text { multiply by }\end{array}\end{array}$ & U.S. unit & SI unit & $\begin{array}{l}\text { To convert SI to U.S., } \\
\text { multiply by }\end{array}$ \\
\hline 0.4047 & acre $(\mathrm{s})$ & $\mathrm{ha}$ & 2.4711 \\
0.0283 & $\mathrm{ft}^{3}$ & $\mathrm{~m}^{3}$ & 35.3147 \\
2.54 & inch $(\mathrm{es})$ & $\mathrm{cm}$ & 0.3937 \\
1 & ppm & $\mathrm{mg} \cdot \mathrm{L}^{-1}$ & 1 \\
$\left({ }^{\circ} \mathrm{F}-32\right) \div 1.8$ & ${ }^{\circ} \mathrm{F}$ & ${ }^{\circ} \mathrm{C}$ & $\left({ }^{\circ} \mathrm{C} \times 1.8\right)+32$
\end{tabular}


is a drying process intended to dry out the necks (Bayat et al., 2010) and outer scales of the bulbs (Maw et al., 2004) to reduce loss of moisture and prevent decay during storage. From harvesting to storage, curing can occur at any stage, whenever the conditions around the bulb become favorable to remove moisture from the bulb (Maw et al., 2004). There are two ways of curing onion bulbs: artificial and natural. Natural curing can take place in the field under the sun and wind after harvest. It is the least expensive way of curing and can be helpful in enhancing onion quality by allowing downward movement of nutrients from tops into the bulb (Maw et al., 1997a). Drying onions by forcing heated air around them is another way of curing. Standard conditions for this type of curing are blowing hot, dry air around the onions with temperatures up to $38{ }^{\circ} \mathrm{C}$ (Maw et al., 1998). Duration of heat curing varies according to the harvest maturity of the bulbs. For immature onions, the duration of heat curing required is more than for onions harvested at optimal maturity. Onions of early maturity are benefited when the duration of heat was $72 \mathrm{~h}$, while for onions of optimal maturity required only $48 \mathrm{~h}$ of heat curing (Maw et al., 1997b).

Based on the market window, short-day onions can be handled in different ways: 1) fresh market, where the onions are sold directly without storage, 2) early-season markets, where the onions are stored in dry, well-ventilated sheds, 3) midseason markets, where onions can be stored under refrigeration, and 4) late season markets, where onions can be stored under refrigeration and controlledatmosphere storage (Maw et al., 1997b). For successful long-term storage of short-day onions, they must be kept in a dormant state, which can be achieved with controlled-atmosphere storage. Controlled-atmosphere storage has been used widely with various fruits and vegetables like apples (Malus $\times$ domestica), pears (Pyrus sp.), kiwis (Actinidia deliciosa), blueberries (Vaccinium sp.), mango (Mangifera indica), bananas (Musa sp.), cabbage (Brassica oleracea var. capitata), chinese cabbage (Brassica rapa), etc. (Kader et al., 1989). In Georgia, Vidalia onions are stored in controlled-atmosphere storage $\left(3 \% \mathrm{O}_{2}\right.$, $5 \% \mathrm{CO}_{2}$ ) at $1-2{ }^{\circ} \mathrm{C}$ and $\mathrm{RH}$ of $75 \%$, which helps in extending the market availability of Vidalia onions from May to September (Boyhan et al., 2008). Sumner (2000) reported good quality Vidalia onions after 7 months of storage under controlled-atmosphere storage.

Sulfur dioxide is not used in onion storage in Georgia, but may offer an alternative to current long-term storage methods. In California, $\mathrm{SO}_{2}$ has been used for the postharvest control of gray mold of table grapes (Vitis vinifera) caused by Botrytis cinerea, (Nelson, 1985). Marois et al. (1986) suggested that controlling gray mold on table grapes under commercial storage conditions was better when $\mathrm{SO}_{2}$ application was at a concentration of $200 \mathrm{mg} \cdot \mathrm{L}^{-1}$ applied three times per week rather than the standard practice of $2500 \mathrm{mg} \cdot \mathrm{L}^{-1}$ once per week. $\mathrm{SO}_{2}$ technology has been tested to control brown rot (Monilinia fructicola) in peaches [Prunus persica (Smith, 1930)], mold in raspberries [Rubussp. (Spayd et al., 1984)], and postharvest decay and peel browning in longan fruit [Dimocarpus longan (Whangchai et al., 2005)]. $\mathrm{SO}_{2}$ does have some drawbacks; it can corrode metal surfaces of the storage chamber and can cause product damage (Rahman, 2007).

Ozone can be helpful in postharvest treatment of fruits and vegetables and is currently used on a limited basis in some onion operations in southern Georgia. It can be applied as a gas or ozonizated water either continuously or intermittently under controlledatmosphere storage (Palou et al., 2001). Storage life of broccoli (B. oleracea var. italica) and cucumber ( $\mathrm{Cucu}^{-}$ mis sativa) can be extended with the help of $\mathrm{O}_{3}$ (Skog and $\mathrm{Chu}, 2001$ ). Song et al. (2000) reported that onion stored at low temperature when exposed to $\mathrm{O}_{3}$ had half of the mold growth compared with the untreated onions.

Gubb and MacTavish (2002) observed that there are a number of factors that can affect the storage life of onions. This includes harvest time, temperature at the time of harvest, bulb composition, number of outer skin layers, and dry matter content. The objective of this study was to determine the influence of varieties, curing, storage atmosphere or fumigation, duration of storage, and poststorage time on marketability of Vidalia onions.

\section{Materials and methods}

This 2-year study evaluated varieties, curing method, storage atmosphere or fumigation, time in storage, and poststorage time. In both years, three varieties, including 'WI-129', 'Sapelo Sweet', and 'Caramelo' were grown according to recommendations of the Georgia Cooperative Extension Service (Boyhan and Kelley, 2007) at the Vidalia Onion and Vegetable Research Center (VOVRC) in Lyons, GA. Eight-week-old seedlings were transplanted in mid-Nov. 2009 and 2010 for the Spring 2010 and 2011 harvests. Harvesting began when onions were judged mature, which is indicated when $20 \%$ to $50 \%$ of the tops have fallen over at the neck or there is significant weakness in the neck. Harvest began with undercutting the onions, 'WI-129', 'Sapelo Sweet', and 'Caramelo' on 26 Apr., 10 May, and 24 May 2010 and 14 Apr., 21 Apr., and 9 May 2011, respectively. During harvest and field curing, rain was recorded in 2010 at the nearby weather station $(\approx 1$ mile from the farm) with 0.05 inch on 25 May 2010. There were no rain events during harvest and field curing in 2011. After undercutting, twothirds of the bulbs were harvested, and transported to the Vidalia Onion Research Laboratory (VORL) in Tifton, GA. The remaining one-third of the undercut bulbs was permitted to field cure for $48 \mathrm{~h}$. In field curing, the soil is shaken from the roots, the tops are not removed, and the onions are placed on the soil surface. Average temperatures in 2010 during harvest and curing ranged from 63 to $75^{\circ} \mathrm{F}$ and in 2011 ranged from 68 to $80^{\circ} \mathrm{F}$. On the same day, the bulbs arrived at VORL, they were cleaned, sorted, and graded manually to choose visually marketable onions of good size for the study. Onions with visual damage, disease, or were misshapen were discarded. Bulbs were segregated into 20-bulb lots and placed into poly mesh bags to insure good air circulation. Half the bags of each variety were then transported to the Black Shank Farm in Tifton, GA, where they were placed one layer deep inside a peanut drier for heat curing $\left(37^{\circ} \mathrm{C}\right)$ by forced air for $48 \mathrm{~h}$. The remainder of the bags were maintained inside the VORL facility without curing $\left(\approx 75^{\circ} \mathrm{F}, 70 \% \mathrm{RH}\right)$. After completion of the 48 -h field cure treatment at VOVRC, bulbs were collected and transported to VORL 
where they were also graded and sorted into 20-bulb lots.

All of the onions from the heat or field curing as well as the uncured onions were placed into one of four cold storage rooms (each having a volume of $12 \mathrm{~m}^{3}$ ) at $1-2^{\circ} \mathrm{C}$ and $70 \% \mathrm{RH}$ at VORL. The four storage rooms were 1) regular air storage [20.95\% $\mathrm{O}_{2}, 0.03 \% \mathrm{CO}_{2}$, and $78 \%$ nitrogen gas $\left(\mathrm{N}_{2}\right)$ ], 2) controlled-atmosphere storage $\left(3 \% \mathrm{O}_{2}, 5 \% \mathrm{CO}_{2}\right.$, and $92 \%$ $\mathrm{N}_{2}$ ), 3) one-time $\mathrm{SO}_{2}$ fumigation followed by regular air storage, or 4) continuous $\mathrm{O}_{3}\left(0.1-10 \mathrm{mg} \cdot \mathrm{L}^{-1}\right.$ continuous exposure) under regular air storage. For the $\mathrm{SO}_{2}$ fumigation treatment in $2010,1000 \mathrm{mg} \cdot \mathrm{L}^{-1}$ of $\mathrm{SO}_{2}$ was injected into a sealed cold storage room and remained at this concentration for $\mathrm{l} \mathrm{h}$, with fans running to help circulate the gas. The concentration was based on the weight of $\mathrm{SO}_{2}$ to meet the concentration for the storage room volume. At the completion of the fumigation, the room was vented with air for 3 to $4 \mathrm{~h}$ until $\mathrm{SO}_{2}$ levels were reduced below detectable levels (less than 1 $\left.\mathrm{mg} \cdot \mathrm{L}^{-1}\right)$. In 2011 , the $\mathrm{SO}_{2}$ treatment used $5000 \mathrm{mg} \cdot \mathrm{L}^{-1}$ of $\mathrm{SO}_{2}$. For the $\mathrm{O}_{3}$ treatment, an $\mathrm{O}_{3}$ generator (XT4000; Air-Zone, Suffolk, VA) was programmed to inject $\mathrm{O}_{3}$ into the room to maintain a continuous exposure between 0.1 and $10 \mathrm{mg} \cdot \mathrm{L}^{-1}$ of $\mathrm{O}_{3} \cdot \mathrm{O}_{3}$ concentration was continuously monitored using an $\mathrm{O}_{3}$ detector (A-21Z; Eco Sensors, Santa Fe, NM). Concentration of the gases, humidity, and temperature were detected by sensors, which were placed inside each storage room under computer control.

Bulb samples were removed after 2 and 4 months of storage, and warmed overnight to room temperature $\left(22^{\circ} \mathrm{C}\right)$ under controlled conditions. The following day, four bags (replications) of each treatment were removed randomly and weighed while a similar set of four bags were maintained at room temperature for $14 \mathrm{~d}$ to evaluate poststorage marketability. Bulbs were evaluated for botrytis neck rot, sour skin (Burkholderia cepacia), slippery skin (Burkholderia gladioli ssp. allicola), physical damage, sprouts, and other storage defects were noted. First, bulbs were evaluated visually for any significant damage or symptoms of diseases, which were considered unmarketable. If there were no defects or disease symptoms observed from the outside, bulbs were then cut longitudinally to see any internal symptoms of disease. Only the bulbs passing both external and internal exams were considered marketable with the primary cause of rejecting bulbs, botrytis neck rot.

Bulbs held for $14 \mathrm{~d}$ under ambient conditions were evaluated in an identical manner as described above. These same procedures were used to evaluate onions stored for 4 months. This experiment was repeated in 2011 .

The experiment was arranged with a full factorial arrangement with five factors as a randomized complete block design with four replications. Three of the five factors were categorical, which included variety, type of curing, and storage conditions, while the remaining two were numerical, months in storage and days after storage before evaluation. The analysis was conducted by splitting the factor model into two separate analyses: one consisting of two factors, varieties and curing methods; the second with storage conditions, months in storage, and poststorage time. This was done to facilitate ease of analyses and to have a more meaningful presentation of the data. Data were collected as percent marketable onions. Analysis of variance was performed on this data. Fisher's protected least significant difference at $P \leq 0.05$ was calculated.

\section{Results and discussion}

For all results, there was a by year interaction so results are presented for years individually. As seen in Table 1 , in 2010, with 'Caramelo' both heat curing and no curing had greater percent marketable onions compared with field curing. For 'Sapelo Sweet' in 2010, heat curing had the greatest percent marketable onions with $78.3 \%$, which was greater than no curing or field curing. 'WI-129' in the same year also had the greatest percent marketable onions with heat curing, which was significantly higher than no curing, but was similar to field curing.

In 2011, 'Caramelo', had no difference between curing methods (Table 1). 'Sapelo Sweet' in 2011 had similar amounts of marketable onions with either field or heat curing, both of which had more marketable onions compared with the no curing treatment. Finally in 2011, with 'WI-129' field curing had the greatest amount of marketable onions with $58.2 \%$, which was greater than heat or no curing.

In 2010, 'Sapelo Sweet' had the greatest amount of marketable onions with $70.1 \%$ marketable compared with either 'WI-129' or 'Caramelo' (Table 1). By contrast, in 2011 both 'Caramelo' and 'Sapelo Sweet' had similar amounts of marketable onions, which were significantly greater than 'WI-129'.

There were interaction effects for storage conditions, varieties, and years so these results are presented separately (Table 2). In both 2010 and 2011, 'Caramelo' had more marketable onions when stored under refrigerated controlled-atmosphere conditions or with refrigerated $\mathrm{O}_{3}$ storage than when stored under refrigeration after $\mathrm{SO}_{2}$ treatment (Table 2). There were no differences between storage conditions in 2010 for 'Sapelo Sweet'; however, in $2011 \mathrm{SO}_{2}$ treatment had the greatest percent marketable onions compared with controlled atmosphere, $\mathrm{O}_{3}$, or refrigeration alone. In 2010, 'WI-129' had the greatest percent marketable onions with controlled atmosphere compared with $\mathrm{O}_{3}$ or simple refrigeration. However, it did not differ from $\mathrm{SO}_{2}$ treatment. In $2011, \mathrm{SO}_{2}$ treatment with 'WI-129' onions had the greatest percent marketable onions at $73.0 \%$, which was significantly better than all other storage conditions. In addition, in 2011 'WI-129' onions stored under controlled-atmosphere conditions had more marketable onions than either refrigeration with $\mathrm{O}_{3}$ or refrigeration alone.

Interactions between storage conditions and time in storage as well as storage conditions and poststorage time were significant. In addition, storage conditions by year and time in storage by year were also significant so these results are presented separately (Table 3). The longer onions were held in storage the lower the percent marketable onions. This was true in both 2010 and 2011. In 2010, there were $\approx 20 \%$ fewer marketable onions after 4 months in storage compared with 2 months in storage. In 2011, there were $\approx 10 \%$ fewer onions from 2 to 4 months in storage.

Onions stored for 2 months in 2010 had the greatest marketable onions with controlled-atmosphere storage, which was significantly better 
Table 1. Percent marketable short-day onion for three varieties after three postharvest curing protocols in $2010-11$.

\begin{tabular}{|c|c|c|c|c|c|c|}
\hline & \multicolumn{3}{|c|}{$2010^{\mathrm{z}}$} & \multicolumn{3}{|c|}{2011} \\
\hline & Caramelo & Sapelo Sweet & WI-129 & Caramelo & Sapelo Sweet & WI-129 \\
\hline Curing method ${ }^{y}$ & \multicolumn{3}{|c|}{ Marketable onions (\%) } & \multicolumn{3}{|c|}{ Marketable onions (\%) } \\
\hline Heat curing & $40.5 \mathrm{a}$ & $78.3 \mathrm{a}$ & $59.4 \mathrm{a}$ & 55.0 & $62.9 \mathrm{a}$ & $48.6 \mathrm{~b}$ \\
\hline No curing & $41.8 \mathrm{a}$ & $63.4 \mathrm{~b}$ & $35.1 \mathrm{~b}$ & 59.8 & $40.4 \mathrm{~b}$ & $41.5 \mathrm{~b}$ \\
\hline \multicolumn{7}{|l|}{ Variety } \\
\hline WI-129 & & $49.8 \mathrm{~b}$ & & & $49.4 \mathrm{~b}$ & \\
\hline \multicolumn{7}{|l|}{ Probabilities } \\
\hline Variety & 0.000 & & & & & \\
\hline Curing method & 0.000 & & & & & \\
\hline Variety $\times$ curing method & 0.000 & & & & & \\
\hline
\end{tabular}

Table 2. Percent marketable onions for three different short-day onion varieties stored under different postharvest environments, 2010-11.

\begin{tabular}{|c|c|c|c|c|c|c|}
\hline & \multicolumn{3}{|c|}{2010} & \multicolumn{3}{|c|}{2011} \\
\hline & Caramelo & Sapelo Sweet & WI-129 & Caramelo & Sapelo Sweet & WI-129 \\
\hline Storage conditions ${ }^{\mathrm{z}}$ & \multicolumn{3}{|c|}{ Marketable onions (\%) } & \multicolumn{3}{|c|}{ Marketable onions (\%) } \\
\hline Controlled atmosphere & $42.0 \mathrm{a}$ & 72.1 & $59.4 \mathrm{a}$ & $63.9 \mathrm{a}$ & $54.2 \mathrm{~b}$ & $50.9 \mathrm{~b}$ \\
\hline Ozone + refrigeration & $42.7 \mathrm{a}$ & 65.1 & $47.5 \mathrm{~b}$ & $64.5 \mathrm{a}$ & $56.5 \mathrm{~b}$ & $39.5 \mathrm{c}$ \\
\hline Sulfur dioxide + refrigeration & $27.2 \mathrm{~b}$ & 73.8 & $55.0 \mathrm{ab}$ & $44.4 \mathrm{~b}$ & $73.1 \mathrm{a}$ & $73.0 \mathrm{a}$ \\
\hline Year & 0.084 & & & & & \\
\hline Storage conditions & 0.000 & & & & & \\
\hline Variety $\times$ storage conditions & 0.000 & & & & & \\
\hline Variety $\times$ year & 0.000 & & & & & \\
\hline Storage conditions $\times$ year & 0.002 & & & & & \\
\hline
\end{tabular}

${ }^{2}$ Refrigeration $=$ storage at $1-2{ }^{\circ} \mathrm{C}\left(33.8-35.6^{\circ} \mathrm{F}\right)$ with $70 \%$ relative humidity.

${ }^{y}$ Means followed by the same letter in each column are not significantly different at $P \leq 0.05$, according to Fisher's protected least significant difference.

Controlled atmosphere $=3 \%$ oxygen, $5 \%$ carbon dioxide, and $92 \%$ nitrogen gas held at $1-2{ }^{\circ} \mathrm{C}$ with $70 \%$ relative humidity

Ozone $=0.1-10 \mathrm{mg} \cdot \mathrm{L}^{-1}(\mathrm{ppm})$ continuous exposure with refrigeration.

Sulfur dioxide $=1000 \mathrm{mg} \cdot \mathrm{L}^{-1}$ in 2010 and $5000 \mathrm{mg} \cdot \mathrm{L}^{-1}$ in 2011 one-time injection with refrigeration.

than refrigeration alone or refrigeration after treatment with $\mathrm{SO}_{2}$ (Table 3). However, controlled-atmosphere storage in 2010 after 2 months of storage did not differ from $\mathrm{O}_{3}$ treatment. In 2011, after 2 months of controlledatmosphere storage, $\mathrm{O}_{3}$ storage, or $\mathrm{SO}_{2}$ treatment all had more marketable onions than refrigeration alone. $\mathrm{SO}_{2}$ treatment, in 2010 after 4 months in storage had the greatest percent marketable onions compared with refrigeration alone, but it did not differ from either controlled-atmosphere storage or $\mathrm{O}_{3}$ storage. In 2011, $\mathrm{SO}_{2}$ again had the greatest percent marketable onions at $67.1 \%$, which was significantly more than refrigeration alone, controlled-atmosphere storage, or $\mathrm{O}_{3}$ storage.

Poststorage time also had a significant effect on marketable onions. The percentage of marketable onions was significantly greater immediately after removal from storage compared with $14 \mathrm{~d}$ later (Table 4).

A number of different conditions were used to determine unmarketable onions (data not shown). These conditions included botrytis neck rot, sour skin, slippery skin, physical damage, shriveled onions, and from unknown causes. Of those onions judged as unmarketable $62.6 \%$ were due to botrytis neck rot, $20.9 \%$ to unknown causes, $6 \%$ to slippery skin, $5.4 \%$ to physical damage, $4.5 \%$ due to sour skin, and $0.6 \%$ were shriveled onions.

Botrytis neck rot's impact on onions varies from year to year and could be difficult to control because the pathogen can enter the bulb 
below the soil line. It is also common for the pathogen to infect neck tissue thus the name. Once the pathogen enters the bulb it is not always obvious after curing. The pathogen in infected onions that are placed in controlled-atmosphere storage will continue to grow, although it is not capable of sporulating (Purvis et al., 2001). Because the pathogen cannot sporulate in controlled-atmosphere storage, bulb losses are primarily due to infections acquired in production. This has resulted in uneven results from this type of storage with the amount of marketable onions varying widely. Anecdotally, severe losses in stored onions occur about once every 4 years. It has been hypothesized that greater losses with stored onions occurs during years when winter temperatures remain low for extended periods of time resulting in slower growth allowing the pathogen to infect onions from below the soil line. Usually as onions are actively growing, particularly early growth, the outer bulb leaves are sloughed off or become the dry papery outer layer of the onion, which helps protect the onion (DeMason, 1990).

In this study, the number of parameters like variety, postharvest curing, storage conditions, duration of storage, and poststorage time were evaluated to assess the influence on percent marketable onions. The results demonstrated clearly that postharvest curing, storage conditions, storage duration, and poststorage time significantly affect the percent of marketable onions. This study documents that all three varieties were significantly different from each other in 2010, but in 2011 only 'WI-129' had significantly less marketable onions. The early harvested variety 'WI$129^{\prime}$ had almost the same percentage of marketable onions for both years. Past studies also support our results that early maturing varieties do not perform as well in storage as mid and late maturing varieties (Boyhan et al., 2008). But there were large differences in the percent marketable onions for the other two varieties. In 2010 , the midseason variety 'Sapelo Sweet' had the highest percent marketable onions. There was a rain event in 2010 during the 'Caramelo' harvest, which probably contributed to the poor performance of this variety that year. However, in 2011, this

Table 3. Effects of postharvest storage conditions, time in storage, and postharvest shelf life on percent marketable short-day onions.

\begin{tabular}{|c|c|c|c|c|}
\hline & \multicolumn{2}{|c|}{2010} & \multicolumn{2}{|c|}{2011} \\
\hline & $2 \mathrm{mo}$. & $4 \mathrm{mo}$. & $2 \mathrm{mo}$. & $4 \mathrm{mo}$. \\
\hline Storage conditions ${ }^{\mathrm{z}}$ & \multicolumn{4}{|c|}{ Marketable onions (\%) } \\
\hline Refrigeration & $60.3 b^{y}$ & $34.0 \mathrm{~b}$ & $50.9 \mathrm{~b}$ & $39.6 \mathrm{~b}$ \\
\hline Controlled atmosphere & $69.2 \mathrm{a}$ & $47.0 \mathrm{a}$ & $66.0 \mathrm{a}$ & $46.8 \mathrm{~b}$ \\
\hline Ozone + refrigeration & $63.4 \mathrm{ab}$ & $40.5 \mathrm{ab}$ & $62.5 \mathrm{a}$ & $44.7 \mathrm{~b}$ \\
\hline Sulfur dioxide + refrigeration & $57.6 \mathrm{~b}$ & $47.7 \mathrm{a}$ & $60.0 \mathrm{a}$ & $67.1 \mathrm{a}$ \\
\hline \multicolumn{5}{|l|}{ Probabilities } \\
\hline Storage conditions & 0.000 & & & \\
\hline Storage time ( 2 or 4 mo.) & 0.000 & & & \\
\hline Poststorage time $(1 \text { or } 14 \mathrm{~d})^{\mathrm{x}}$ & 0.000 & & & \\
\hline Year & 0.128 & & & \\
\hline Storage conditions $\times$ storage time & 0.000 & & & \\
\hline Storage conditions $\times$ poststorage time & 0.009 & & & \\
\hline Storage time $\times$ poststorage time & 0.162 & & & \\
\hline $\begin{array}{l}\text { Storage conditions } \times \text { storage } \\
\text { time } \times \text { poststorage time }\end{array}$ & 0.270 & & & \\
\hline Storage conditions $\times$ year & 0.002 & & & \\
\hline Storage time $\times$ year & 0.001 & & & \\
\hline Poststorage time $\times$ year & 0.116 & & & \\
\hline
\end{tabular}

${ }^{\mathrm{z}}$ Refrigeration $=$ storage at $1-2{ }^{\circ} \mathrm{C}\left(33.8-35.6^{\circ} \mathrm{F}\right)$ with $70 \%$ relative humidity.

yeans followed by the same letter in each column are not significantly different at $P \leq 0.05$, according to Fisher's protected least significant difference.

${ }^{x}$ Poststorage time $=$ after removal from storage onions were evaluated immediately (day 1 ) or held under ambient conditions $\left[\approx 24^{\circ} \mathrm{C}\left(75.2{ }^{\circ} \mathrm{F}\right)\right]$ for $14 \mathrm{~d}$ before evaluating for marketability.

Controlled atmosphere $=3 \%$ oxygen, $5 \%$ carbon dioxide, and $92 \%$ nitrogen gas held at $1-2{ }^{\circ} \mathrm{C}$ with $70 \%$ relative humidity.

Ozone $=0.1-10 \mathrm{mg} \cdot \mathrm{L}^{-1}(\mathrm{ppm})$ continuous exposure with refrigeration

Sulfur dioxide $=1000 \mathrm{mg} \cdot \mathrm{L}^{-1}$ in 2010 and $5000 \mathrm{mg} \cdot \mathrm{L}^{-1}$ in 2011 one-time injection with refrigeration.

variety did much better comparable to 'Sapelo Sweet' and better than 'WI-129'.

Botrytis neck rot is the primary storage disease of onions in the southeastern United States, with infection starting in the field. Cool, moist weather conditions before or at the time of harvest favors the disease and can cause more losses in storage (Johnson, 1986). Harvesting after rain events should be avoided to insure a quality product goes into storage. Similarly, if rain is in the 48 - to 72 -h forecast, heat curing of harvested onions may be advisable over field curing to reduce the risk of wet bulbs being placed into storage.

Curing in general helps onions store better and for longer periods (Maw et al., 2005). Our study also generally indicated that curing had a significant positive impact on percent marketable onions. However, this was not as clear-cut as in previous studies. The low percent marketable onions with 'Caramelo' in 2010 after field curing can be explained, we believe, by the rain event during field curing that year. Uncured 'Sapelo Sweet' onions did as well as field curing in 2010 and there was no difference
Table 4. Poststorage marketable onions after 1 or $14 \mathrm{~d}$ under ambient conditions $\left[\approx 24{ }^{\circ} \mathrm{C}\left(75.2^{\circ} \mathrm{F}\right)\right]$ from onions combined from various storage conditions and stored for both 2 and 4 months.

\begin{tabular}{lc}
\hline $\begin{array}{l}\text { Poststorage } \\
\text { time (d) }\end{array}$ & $\begin{array}{c}\text { Marketable } \\
\text { onions (\%) }\end{array}$ \\
\hline 1 & 63.2 \\
14 & 44.1 \\
Probability $^{\mathrm{z}}$ & 0.000 \\
\hline
\end{tabular}

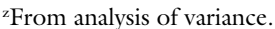

between cured and uncured 'Caramelo' onions in 2011. Finally in 2011, uncured 'WI-129' onions did as well as heat-cured onions, but not as well as field-cured onions.

Storing onions under different conditions had an impact on onion marketability. The greater percent marketable onions under $\mathrm{SO}_{2}$ treatment in 2011 may be related to the higher treatment concentration of $\mathrm{SO}_{2}$ in 2011 , which was applied at 5000 $\mathrm{mg} \cdot \mathrm{L}^{-1}$ in 2011 compared with 1000 $\mathrm{mg} \cdot \mathrm{L}^{-1}$ in $2010 . \mathrm{SO}_{2}$ may be a viable alternative to controlled-atmosphere storage, which is widely used in the industry, because it would be less expensive. In 2010, $\mathrm{SO}_{2}$ was as good 
as controlled-atmosphere storage with 'Sapelo Sweet' and 'WI-129' and in 2011 , it was the best overall with 'Sapelo Sweet' and 'WI-129'. There was no direct injury detected in the onions treated with $\mathrm{SO}_{2}$.

Overall, no clear-cut onion storage condition appeared to consistently result in more percent marketable onions. Even if 'Caramelo' onions from 2010 are excluded due to the rain event during harvest and field curing, there were no differences with 'Sapelo Sweet' that year and storage conditions other than simple refrigeration were better for 'WI-129'. In 2011, $\mathrm{SO}_{2}$ was the best storage method for 'Sapelo Sweet' and 'WI-129'; however, for 'Caramelo' it was the worst. Although not clearcut, $\mathrm{SO}_{2}$ may offer a viable alternative to current storage methods for shortday onions in Georgia.

\section{Literature cited}

Bayat, F., S. Rezvani, and A.E. Nosrati. 2010. Effect of harvesting time and curing temperature on some properties of Iranian white garlic. Acta Hort. 877:869875.

Boyhan, G., D. MacLean, T. Bateman, R. Hill, and D. Thigpen. 2008. Preliminary evaluation of storage conditions and varieties effect on Vidalia onion marketability and weight loss. 2008 Georgia Onion Res. Ext. Rpt. Coop. Res. Ext. Publ. No. 3-2008.

Boyhan, G.E. and R.L. Torrance. 2002. Vidalia onions-Sweet onion production in southeastern Georgia. HortTechnology 12:196-202.

Boyhan, G. and W.T. Kelley (eds.). 2007. Onion production guide. Univ. Georgia Coop. Ext. Serv. Bul. 1198.

Brewster, J.L. 1990. Physiology of crop growth and bulbing, p. 53-81. In: H.D. Rabowitch and J.L. Brewster (eds.). Onions and allied crops. Vol. 1. Botany, physiology, and genetics. CRC Press, Boca Raton, FL.

DeMason, D.A. 1990. Morphology and anatomy of Allium, p. 27-51. In: H.D. Rabinowitch and J.L. Brewster (eds.). Onions and allied crops. Vol. 1. Botany, physiology, and genetics. CRC Press, Boca Raton, FL.

Food and Agriculture Organization of the United Nations. 2014. FAO statistical databases. 23 Oct. 2014. <http:// faostat3.fao.org/home/E>.

Gubb, I.R. and H.S. MacTavish. 2002. Onion pre- and postharvest considerations, p. 233-266. In: H.D. Rabinowitch and L. Currah (eds.). Allium crop sciences: Recent advances. CAB International, Wallingford, UK.

Johnson, D.A. 1986. Botrytis neck rot of onion. Washington State Coop. Ext. Bul. 1359.

Kader, A.A., D. Zagory, and E.L. Kerbel. 1989. Modified atmosphere packaging of fruits and vegetables. CRC Crit. Rev. Food Sci. Nutr. 28:1-30.

Marois, J.J., A.M. Bledsoe, W.D. Gubler, and D.A. Luvisi. 1986. Control of Botrytis cinerea on grape berries during postharvest storage with reduced levels of sulfur-dioxide. Plant Dis. 70:1050-1052.

Maw, B.W., B.G. Mullinix, and D.A. Smittle. 1997a. Artificially curing sweet onions. Appl. Eng. Agr. 13:517-520.

Maw, B.W., B.G. Mullinix, and D.A. Smittle. 1997b. The influence of harvest maturity, curing and storage conditions upon the storability of sweet onions. Appl. Eng. Agr. 13:511-515.

Maw, B.W., C.L. Butts, A.C. Purvis, K. Seebold, and B.G. Mullinix. 2004. Hightemperature continuous-flow curing of sweet onions. Appl. Eng. Agr. 20:657663.

Maw, B.W., J.T. Paulk, G. Boyhan, and R. Hill. 2005. Ozonation of sweet onions during curing. 2005 Georgia Onion Res. Ext. Rpt. Coop. Res. Ext. Publ. No. 32005.

Maw, B.W., R.G. Gitaitis, A.C. Purvis, and D.R. Sumner. 1998. Curing Vidalia (sweet) onions. 1996-97 Georgia Onion Res. Ext. Rpt. 3-98.

Nelson, K.E. 1985. Harvesting and handling California table grapes for market. Univ. California Bul. No. 1913.

Palou, L., J.L. Smilanick, C.H. Crisosto, and M. Mansour. 2001. Effect of gaseous ozone exposure on the development of green and blue molds on cold stored citrus fruit. Plant Dis. 85:632-638.

Pappelis, A.J., G.A. Pappelis, and F.B. Kulfinsk. 1974. Nuclear orientation in onion epidermal-cells in relation to wounding and infection. Phytopathology 64:10101012.

Purvis, A.C., J.H. Brock, and J.T. Paulk. 2001. Does botrytis spread to sound onions in storage? Georgia 2000 Onion Res.-Ext. Rpt. Coop. Res.-Ext. Publ. No. 3-2001. p. 47-50.

Rahman, M.S. (ed.). 2007. Handbook of food preservation. 2nd ed. CRC Press, Boca Raton, FL.

Sanders, Jr., F.H., D.B. Langston, Jr., and M.J. Foster. 2008. Effect of fungicide dip treatments on fungal diseases and yield of transplanted sweet onions. 2008 Georgia Onion Res. Ext. Rpt. Coop. Res. Ext. Publ. No. 3-2008.

Skog, L.J. and C.L. Chu. 2001. Effect of ozone on qualities of fruits and vegetables in cold storage. Can. J. Plant Sci. 81:773-778.

Smith, M.A. 1930. Sulphur dust for the control of brown rot of peaches in storage. Phytopathology 20:122-123.

Song, J., L. Fan, P.D. Hildebrand, and C.F. Forney. 2000. Biological effects of corona discharge on onions in a commercial storage facility. HortTechnology 10:608612 .

Spayd, S.E., R.A. Norton, and L.D. Hayrynen. 1984. Influence of sulfur dioxide generators on red raspberry quality during postharvest storage. J. Food Sci. 49:1067-1069.

Sumner, P. 2000. Vidalia onion CA storage requirments. 12 Nov. 2012. <http:// www.caes.uga.edu/commodities/fruits/ $\mathrm{ve} \mathrm{g/p} \mathrm{u} \mathrm{b} \mathrm{s/d} \mathrm{o} \mathrm{c} \mathrm{u} \mathrm{m} \mathrm{e} \mathrm{n} \mathrm{t} \mathrm{s} \mathrm{/}$ vidaliaonioncastoragerequirements.pdf $>$.

Whangchai, K., K. Saengnil, and J. Uthaibutra. 2005. Control of postharvest diseases in longan fruit by ozone. Acta Hort. 682:2121-2126.

Wolfe, K. and A.L. Morgan. 2011. 2010 Georgia farm gate value report. Univ. of Ga. Ctr. Agribusiness Econ. Dev. Rpt. AR-11-01. 